\title{
Bony fishes (Teleostei) caught by small-scale fisheries off central to south coast of São Paulo State, Southeastern Brazil
}

\author{
Fabio Santos Motta ${ }^{1,4,5}$, Marcos Rogério Rosa ${ }^{2}$, Rafael Cabrera Namora ${ }^{3}$ \& Otto Bismarck Fazzano Gadig ${ }^{4}$ \\ ${ }^{1}$ Departamento de Ciências do Mar, Universidade Federal de São Paulo, Santos, SP, Brazil. \\ ${ }^{2}$ Instituto Linha D' Água, Pinheiros, São Paulo, SP, Brazil. \\ ${ }^{3}$ Instituto de Pesca, Programa de Monitoramento da Atividade Pesqueira, Santos, SP, Brasil. \\ ${ }^{4}$ Laboratório de Pesquisa em Elasmobrânquios, Universidade Estadual Paulista Júlio de Mesquita Filho, \\ São Vicente, SP, Brazil. \\ ${ }^{5}$ Corresponding author: Fabio Santos Motta, e-mail: limbatus@gmail.com
}

MOTTA, F.S., ROSA, M.R., NAMORA, R.C., GADIG, O.B.F. Bony fishes (Teleostei) caught by smallscale fisheries off central to south coast of São Paulo State, Southeastern Brazil. Biota Neotropica. 14(4): e20140007. http://dx.doi.org/10.1590/1676-06032014000714

\begin{abstract}
Small-scale fisheries have a great socioeconomic importance in Brazil. Different regional characteristics along the coast, mostly related to landing sites, equipment used, and targeted species, renders its assessment and monitoring difficult. The aim of this paper is to present a list of species of bony fishes (Teleostei) caught by artisanal fisheries along the São Paulo coast, southeastern Brazil and to provide comments on the relative abundance and conservation status of those species. A total of 315 fishing fleet landings were surveyed, and 106 species distributed among 38 families were recorded. Sciaenidae and Carangidae were the most frequent families in species number. The southern king weakfish, Macrodon atricauda, was the most abundant species, representing $28.03 \%$ of the total number of specimens caught. Eleven of the most abundant species are classified as Overexploited in the country or as Near Threatened in the state of São Paulo. These findings reinforce the relevance of assessing and managing artisanal fisheries.
\end{abstract}

Keywords: artisanal fisheries, ichthyofauna, species list, western Atlantic.

MOTTA, F.S., ROSA, M.R., NAMORA, R.C., GADIG, O.B.F. Peixes ósseos (Teleostei) capturados pela pesca de pequena escala na costa centro-sul de São Paulo, Sudeste do Brasil. Biota Neotropica. 14(4): e20140007. http://dx.doi.org/10.1590/1676-06032014000714

Resumo: A pesca de pequena escala tem uma grande importância socioeconômica no Brasil. Diferenças regionais ao longo da costa, relacionadas principalmente aos locais de desembarque, artes de pesca e espécies- alvo tornam a sua avaliação e monitoramento difíceis. O objetivo do presente estudo foi apresentar uma lista das espécies de peixes ósseos capturadas pela pesca artesanal na costa de São Paulo, sudeste do Brasil, com comentários sobre a sua abundância relativa e estado de conservação. Foram monitorados 315 desembarques da frota pesqueira, registrando 106 espécies, distribuídas em 38 famílias. As famílias Sciaenidae e Carangidae foram as mais representativas em número de espécies. A pescada amarela, Macrodon atricauda, foi a espécie mais abundante, correspondendo a 28,03\% do número total de peixes capturados. Onze das espécies mais abundantes são classificadas como Sobre-explotadas no país ou Próximo de Ameaça de Extinção no estado de São Paulo. Esses resultados reforçam a relevância de avaliar e manejar as pescarias artesanais.

Palavras-chave: pesca artesanal, ictiofauna, lista de espécies, Atlântico Ocidental.

\section{Introduction}

Despite a lack of government support, small-scale fisheries still have high socioeconomic relevance along the Brazilian coast, with about one million people involved in this activity (Vasconcellos et al. 2011). Even in the southeast region, where industrial fisheries account for most landings, the artisanal sector is still responsible for almost $40 \%$ of production (Vasconcellos et al. 2007). This situation reinforces the importance of understanding, assessing and effectively managing coastal fisheries (Salas et al. 2011). However, statistical data and basic information, including the species richness of fishes caught, are both still scarce and incomplete (Alves et al. 2009, Salas et al. 2011).

In São Paulo state, southern Brazil, most of the fish species inventories conducted have occurred along the northern and central coasts (Braga \& Goitein 1984, Lopes et al. 1993, Giannini \& Paiva-Filho 1995, Muto et al. 2000, Gibran \& Moura 2012). Few surveys have focused on the southern to central portion of the São Paulo coast (e.g. Zani-Teixeira \& 
Paiva-Filho 1981). All of the studies cited were also based on scientific collecting and are therefore not adequate for evaluating the interaction between artisanal fisheries and coastal fish assemblages. This paper provides a checklist of the species of bony fishes (Actinopterygii: Teleostei) caught by small-scale fisheries along the central to south coast of São Paulo state. Comments on the relative abundance and conservation status of the species recorded are also included.

\section{Materials and Methods}

This report is associated with a long-term research on the fishery biology of coastal elasmobranchs off southeastern Brazil (PROJETO CAÇÃO), started in 1996 (Gadig et al. 2002). Species were recorded based on weekly sampling from artisanal fisheries that operate along the central to south coast of São Paulo state. The samplings were taken from landings on the "Praia dos Pescadores" (Fishermen's Beach), city of Itanhaém ( $\left.24^{\circ} 11^{\prime} \mathrm{S} ; 46^{\circ} 48^{\prime} \mathrm{W}\right)$.

The fishing operations in question cover an area of approximately $600 \mathrm{~km}^{2}$, with the cities of Mongaguá and Peruibe making up the northern and southern limits, respectively (Figure 1). This region lies within the inner continental shelf, with a mean water temperature of $24^{\circ} \mathrm{C}$ and an average salinity of 34.5 (Freitas \& Muelbert, 2004). The substrate is largely composed of fine sand, with less than $30 \%$ calcium carbonate (Figueiredo \& Tessler, 2004). Primary productivity in the region is mainly driven by seasonal upwellings of nutrientrich, cold subtropical waters caused by alongshore winds and by cyclonic vortices that come from the Brazil Current (Bakun \& Parrish 1990, Matsuura 1995, Vasconcellos \& Gasalla 2001).

This fishery fleet consists of approximately 28 smallmotorized boats (4-10 m long), which fish mainly with gillnets and single shrimp otter trawl nets. Gillnets are made of nylon

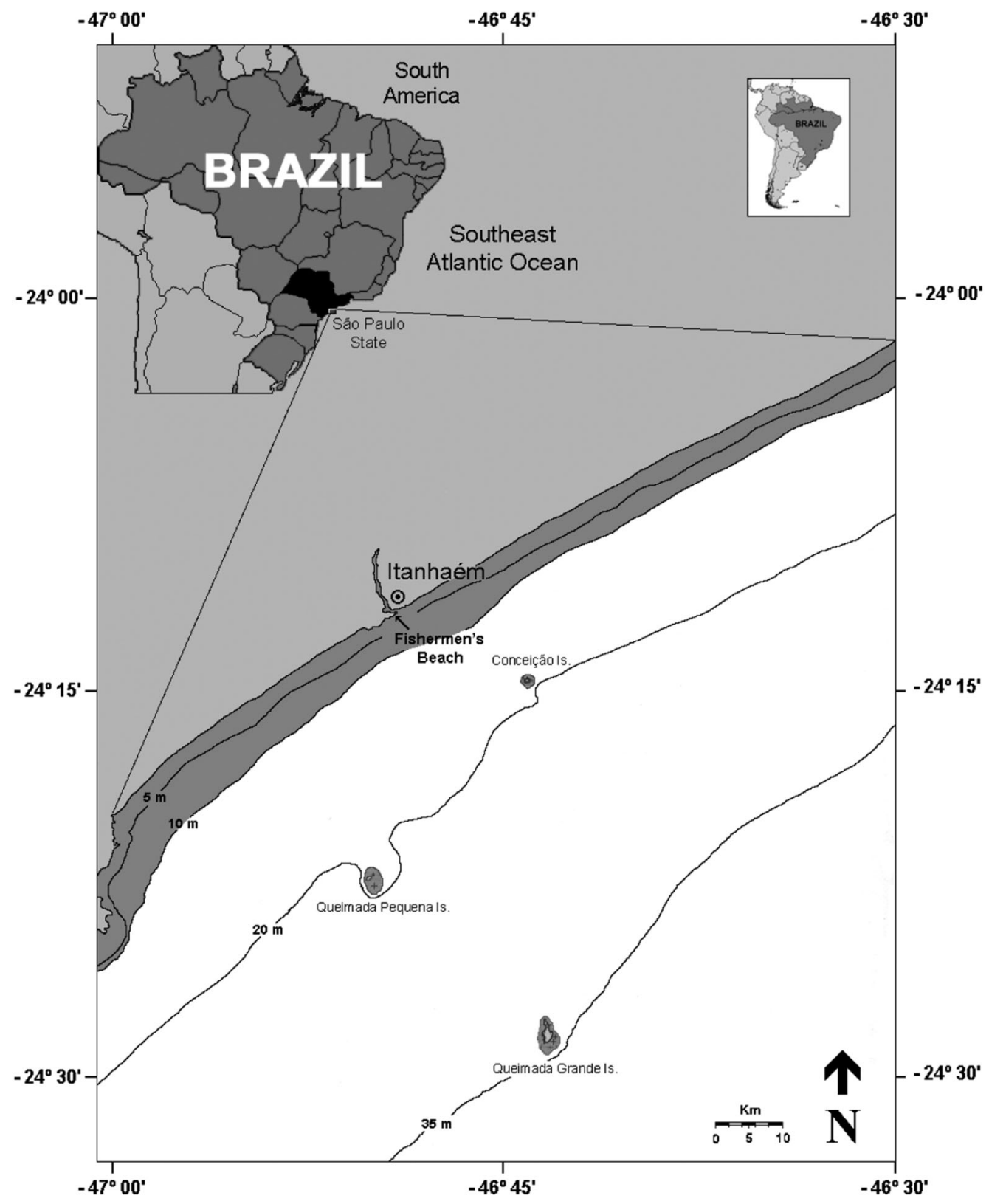

Figure 1. Map of study area, indicating the landing point of the small-scale fishery fleet in Itanhaém, southeastern Brazil. 
Table 1. Checklist of species of the Teleostei captured by small-scale fisheries in the central to south coast of São Paulo State, Southeastern Brazil. Conservation status according to different level assessments: Needing Management Actions (NMA), Overexploited (OE), Data-Deficient (DD), Least-Concern (LC), Near-Threatened (NT), Vulnerable (VU); Endangered (EN), not evaluated species (-).

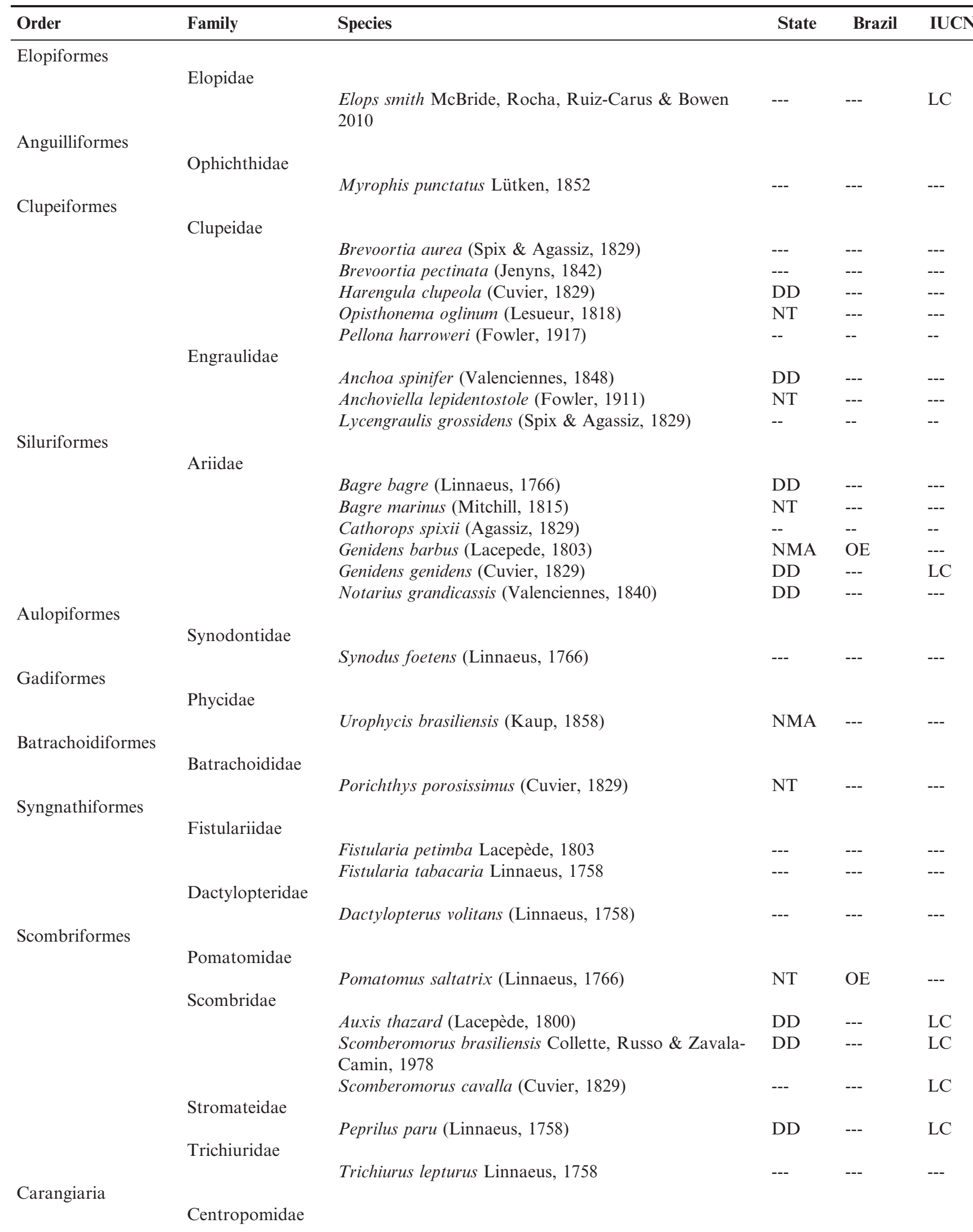


Table 1. Continued.

\begin{tabular}{|c|c|c|c|c|c|}
\hline Order & Family & Species & State & Brazil & IUCN \\
\hline & & Centropomus parallelus Poey, 1860 & NT & --- & --- \\
\hline & & Centropomus undecimalis (Bloch, 1792) & NT & --- & --- \\
\hline & Polynemidae & & & & \\
\hline & & Polydactylus virginicus (Linnaeus, 1758) & -- & -- & -- \\
\hline & Sphyraenidae & & & & \\
\hline & & Sphyraena barracuda (Edwards, 1771) & DD & --- & --- \\
\hline & & Sphyraena guachancho Cuvier, 1829 & DD & --- & --- \\
\hline \multicolumn{6}{|c|}{ Carangiformes } \\
\hline & Carangidae & & & & \\
\hline & & Carangoides bartholomaei (Cuvier, 1833) & --- & --- & --- \\
\hline & & Caranx crysos (Mitchill, 1815) & --- & --- & $\mathrm{LC}$ \\
\hline & & Caranx hippos (Linnaeus, 1766) & --- & --- & --- \\
\hline & & Caranx latus Agassiz, 1831 & -- & -- & -- \\
\hline & & Chloroscombrus chrysurus (Linnaeus, 1766) & -- & -- & -- \\
\hline & & Hemicaranx amblyrhynchus (Cuvier, 1833) & -- & -- & -- \\
\hline & & Oligoplites palometa (Cuvier, 1832) & -- & -- & -- \\
\hline & & Oligoplites saliens (Bloch, 1793) & -- & -- & -- \\
\hline & & Oligoplites saurus (Bloch \& Schneider, 1801) & -- & -- & -- \\
\hline & & Parona signata (Jenyns, 1841) & -- & -- & -- \\
\hline & & Selene setapinnis (Mitchill, 1815) & NT & -- & -- \\
\hline & & Selene vomer (Linnaeus, 1758) & NT & -- & -- \\
\hline & & Trachinotus carolinus (Linnaeus, 1766) & -- & -- & -- \\
\hline & & Trachinotus falcatus (Linnaeus, 1758) & -- & -- & -- \\
\hline & & Trachinotus goodei Jordan \& Evermann, 1896 & -- & -- & $\mathrm{LC}$ \\
\hline & & Trachinotus marginatus Cuvier, 1832 & -- & -- & -- \\
\hline & Coryphaenidae & & & & \\
\hline & & Coryphaena hippurus Linnaeus, 1758 & DD & -- & $\mathrm{LC}$ \\
\hline & Rachycentridae & & & & \\
\hline & & Rachycentron canadum (Linnaeus, 1766) & & -- & -- \\
\hline \multicolumn{6}{|c|}{ Pleuronectiformes } \\
\hline & Achiridae & & & & \\
\hline & & Trinectes microphthalmus (Chabanaud, 1928) & DD & -- & -- \\
\hline & & Trinectes paulistanus (Miranda Ribeiro, 1915) & DD & -- & -- \\
\hline & Cynoglossidae & & & & \\
\hline & & Symphurus tessellatus (Quoy \& Gaimard, 1824) & -- & -- & -- \\
\hline & Paralichthyidae & & & & \\
\hline & & Citharichthys spilopterus Günther, 1862 & DD & -- & -- \\
\hline & & Syacium papillosum (Linnaeus, 1758) & DD & -- & -- \\
\hline & & Paralichthys brasiliensis (Ranzani, 1842) & NT & -- & -- \\
\hline & & Paralichthys patagonicus Jordan, 1889 & NT & -- & -- \\
\hline \multicolumn{6}{|c|}{ Mugiliformes } \\
\hline & Mugilidae & & & & \\
\hline & & Mugil lisa Valenciennes, 1836 & NMA & -- & -- \\
\hline & & Mugil curema Valenciennes, 1836 & $\mathrm{DD}$ & -- & -- \\
\hline \multicolumn{6}{|c|}{ Eupercaria } \\
\hline & Gerreidae & & & & \\
\hline & & Diapterus rhombeus (Cuvier, 1829) & -- & -- & -- \\
\hline & & Eucinostomus argenteus Baird \& Girard, 1855 & -- & -- & -- \\
\hline & & Eugerres brasilianus (Cuvier, 1830) & $\mathrm{DD}$ & -- & -- \\
\hline & Haemulidae & & & & \\
\hline & & Anisotremus surinamensis (Bloch, 1791) & -- & -- & -- \\
\hline & & Anisotremus virginicus (Linnaeus, 1758) & -- & -- & -- \\
\hline & & Boridia grossidens Cuvier, 1830 & $\mathrm{DD}$ & -- & -- \\
\hline & & Conodon nobilis (Linnaeus, 1758) & $\mathrm{DD}$ & -- & -- \\
\hline & & Haemulon steindachneri (Jordan \& Gilbert, 1882) & -- & -- & $\mathrm{LC}$ \\
\hline & & Orthopristis ruber (Cuvier, 1830) & NT & -- & -- \\
\hline & & Pomadasys corvinaeformis (Steindachner, 1868) & -- & -- & -- \\
\hline
\end{tabular}


Table 1. Continued.

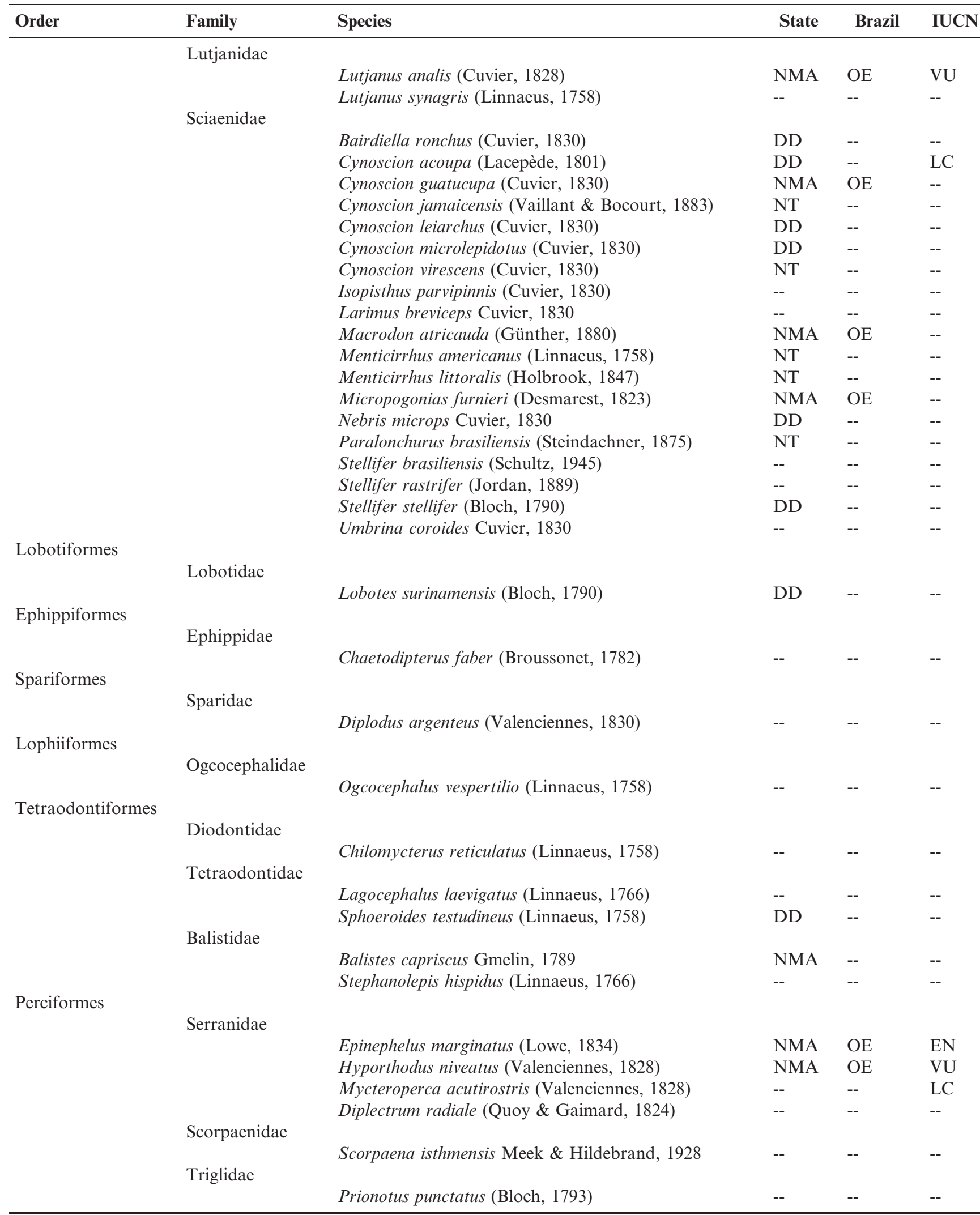

Vouchers used as reference: Rachycentron canadum AZUSC 165, Hyporthodus niveatus AZUSC 424, Synodus foetens AZUSC 431, Stephanolepis hispidus AZUSC 898, Parona signata AZUSC 3654 
monofilament with $1500 \mathrm{~m}$ in length and stretched mesh sizes varying between 7 and $14 \mathrm{~cm}$. The height of the nets varies between 1.7 and $3.5 \mathrm{~m}$. Nets were set up between 12 to 24 hours, within an area of 0.5 to 12 nautical miles from the shore, in waters between 5 and $35 \mathrm{~m}$ deep. Other fishing gear used seasonally include driftnet, trammel nets and large-sized gillnets. More detailed descriptions of those fisheries are presented by Namora et al. (2009). There are two marine protected areas in the region, the "Tupiniquins" Ecological Station (corresponding to IUCN Category Ia), created in 1986, with an area of $20 \mathrm{~km}^{2}$, and the "Litoral Centro" Environmental Protected Area (corresponding to IUCN Category V), established in 2008 and comprising an area of $4,531 \mathrm{~km}^{2}$.

This checklist was based on 315 fishery fleet landings monitored between July 1996 and March 2007. To evaluate the relative abundance of species, 33 field campaigns were carried out in order to count the specimens landed between April 2004 and October 2006. The orders and families were listed in phylogenetic order according to Betancur-R et al. (2014), and the species were organized within each family in alphabetical order. The conservation status of the species were based on global (IUCN 2013), national (Machado et al. 2005), and regional (São Paulo State 2014) levels. Voucher specimens of the some species collected during the study were deposited in the ichthyology collection of the "Acervo Zoológico da Unisanta" (AZUSC), in the city of Santos, São Paulo.

\section{Results and Discussion}

A total of 106 species, distributed among 78 genera, 38 families and 20 orders of the Teleostei were recorded (Table 1) over 10 years. The most speciose family recorded was Sciaenidae $(19$ species $=17.9 \%)$, followed by Carangidae $(16$ $=15.1 \%)$, Haemulidae $(7=6.6 \%)$, Ariidae $(6=5.7 \%)$, Clupeidae $(5=4.7 \%)$, and Serranidae $(4=3.8 \%)$.

The number of species recorded is higher than the amounts recorded during previous experimental studies conducted with beach or otter trawl nets in other regions off the coast of São Paulo state. Braga \& Goitein (1984), for instance, recorded 57 species, whereas Lopes et al. (1993), Giannini \& Paiva-Filho (1995) and Muto et al. (2000) recorded 78, 98 species, and 83 species, respectively. When compared to monitoring of fishing activities in adjacent areas, the number of species recorded in this study is approximately 2.5 times higher than that of Bertozzi \& Zerbini (2002), which recorded 42 species off the city of "Praia Grande". The difference in terms of number of recorded species in this study is likely related to several factors, including the total area of operation of the fleet surveyed, the fishing gear selectivity, the magnitude of both sampling and fishing effort, and the spatial and temporal distribution of species. In the current study, for instance the fishing operation area and the magnitude of sampling and fishing effort were higher than those previous studies.

Between April 2004 and October 2006, 11,443 fish specimens of 74 species, 59 genera and 31 families were recorded. The southern king weakfish, Macrodon atricauda (Günther, 1880), and the gulf kingcroaker, Menticirrhus littoralis (Holbrook, 1847), were the most abundant species, representing $28.03 \%$ and $12.48 \%$ of the total number of specimens recorded, respectively (Table 2). Among the 20 most abundant species, 10 $(50 \%)$ belonged to Sciaenidae. This finding highlight the abundance of the group in the coastal waters and its relevance
Table 2. Relative abundance ( $>0.5 \%$ of the total catch) of species caught by small-scale fisheries in the central to south coast of São Paulo State, Southeastern Brazil, between April 2004 and October 2006. Number of specimens (N); Percentage of the total catch (\%).

\begin{tabular}{lll}
\hline Species & $\mathbf{N}$ & $\%$ \\
\hline Macrodon atricauda & 3208 & 28.03 \\
Menticirrhus littoralis & 1428 & 12.48 \\
Larimus breviceps & 781 & 6.83 \\
Bagre bagre & 701 & 6.13 \\
Oligoplites saliens & 673 & 5.88 \\
Stellifer rastrifer & 670 & 5.86 \\
Micropogonias furnieri & 621 & 5.43 \\
Nebris microps & 351 & 3.07 \\
Trichiurus lepturus & 262 & 2.29 \\
Scomberomorus brasiliensis & 252 & 2.20 \\
Genidens barbus & 249 & 2.18 \\
Bagre marinus & 226 & 1.98 \\
Notarius grandicassis & 221 & 1.93 \\
Paralonchurus brasiliensis & 182 & 1.59 \\
Chloroscombrus chrysurus & 156 & 1.36 \\
Menticirrhus americanus & 139 & 1.21 \\
Cynoscion virescens & 127 & 1.11 \\
Stellifer brasiliensis & 122 & 1.07 \\
Peprilus paru & 119 & 1.04 \\
Genidens genidens & 104 & 0.91 \\
Cynoscion jamaicencis & 92 & 0.80 \\
Isopisthus parvipinnis & 72 & 0.63 \\
Selene setapinnis & 67 & 0.59 \\
Centropomus undecimalis & 60 & 0.52 \\
\hline
\end{tabular}

to artisanal fisheries. Previous studies conducted off the coast of São Paulo state also reported a relative dominance of Sciaenidae species (Braga \& Goitein 1984, Lopes et al. 1993, Giannini \& Paiva-Filho 1995, Muto et al. 2000).

Out of the total number of species recorded, $59(55.6 \%)$ have had their conservation statuses assessed on at least one geographic scale. At the global level, one species was evaluated as Endangered (Epinephelus marginatus), two species were considered Vulnerable (Hyporthodus niveatus and Lutjanus analis) and 12 were considered to be of Least Concern (Table 1). Regional and national assessments have adopted other categories in addition to those provided by the IUCN. At the national level (on the Brazilian list), eight species were considered Overexploited (Table 1), whereas in the São Paulo state list, ten species were evaluated as Needing Management Actions, 17 were considered to be Near Threatened, and 27 were categorized as Data Deficient (Table 1). There is particular concern over the fact that 11 of the most frequently captured species are considered "Overexploited" (Macrodon atricauda, Micropogonias furnieri, Genidens barbus) or "Near Threatened" (Bagre marinus, Paralonchurus brasiliensis, Cynosciun virescens, Cynoscion jamaicencis, Paralonchurus brasiliensis, Menticirrhus americanus, Menticirrhus littoralis, Paralonchurus brasiliensis), reinforcing the importance of assessment programs and management actions for these fisheries.

\section{Acknowledgements}

The authors thank the fishermen of Itanhaém for their collaboration with PROJETO CACÃO, for their friendship, and for their permission to examine all fish specimens landed, 
and to grant \# 1999/04085-1, São Paulo Research Foundation (FAPESP) and the Brazilian Council for Scientific Research (CNPq) for the grants to F. S. Motta and O. B. F. Gadig, respectively. The authors are also grateful to reviewers for comments that greatly improved the manuscript.

\section{References}

AlveS, P.M.F., ARFELli, C.A. \& TOMÁS, A.R.G. 2009. Caracterização da pesca de emalhe do litoral do Estado de São Paulo, Brasil. Bol. Inst. Pesca. 35(1):17-27.

BAKUN, A. \& PARRISH, R. 1990. Comparative studies of coastal pelagic fish reproductive habitat: the Brazilian sardine (Sardinella aurita). J. Cons. Int. Explor. Mer. 46:269-283, http://dx.doi.org/ 10.1093/icesjms/46.3.269

BERTOZZI, C.P. \& ZERBINI, A.N. 2002. Incidental mortality of franciscana (Pontoporia blainvillei) in the artesanal fishery of Praia Grande, São Paulo State, Brazil. LAJAM. 1(1):153-160, http:// dx.doi.org/10.5597/lajam00019

BETANCUR-R, R., WILEY, E., BAILly, N., MIYA, M., LECOINTRE, G., ORTÍ, G. 2014. Phylogenetic Classification of Bony Fishes --Version 3 (http://www.deepfin.org/Classification_v3. htm) (accessed on 20 October 2014).

BRAGA, F.M.S. \& GOITEIN, R. 1984. Lista prévia das espécies de peixes demersais na região da Ilha Anchieta (Lat. $23^{\circ} 33^{\prime} \mathrm{S}$ - Long. $45^{\circ}$ 05), Ubatuba, litoral norte do Estado de São Paulo, Brasil. Naturalia. 9:61-72.

FIGUEIREDO, A.G. \& TESSLER, M.G. 2004. Topografia e composição do substrato marinho da região Sudeste-Sul do Brasil. São Paulo, Instituto Oceanográfico, USP - Série Documentos do Revizee: Score Sul, 64p.

FREITAS, D.M. \& MUELBERT, J.H. 2004. Ichthyoplankton distribution and abundance off southeaster and Southern Brazil. Braz. Arch. Biol. Techn. 47(4):601-612, http://dx.doi.org/10.1590/ S1516-89132004000400014

GADIG, O.B.F., MOTTA, F.S. \& NAMORA, R.C. 2002. Projeto Cação: a study on small coastal sharks in São Paulo, southeast Brazil. In: Duarte, P. (ed.) Proceedings fo the International Conference on Sustainable Management of Coastal Ecosystems. Universidade Fernando Pessoa, Porto, Portugal. p. 239-246.

GIANNINI, R. \& PAIVA-FILHO, A.M. 1995. Análise comparativa da ictiofauna da zona de arrebentação de praias arenosas do Estado de São Paulo, Brasil. Bol. Inst. Ocean. 43(2):141-152.

GIBRAN, F.Z. \& MOURA, R.L. 2012. The structure of rocky reef fish assemblages across a nearshore to coastal islands'gradient in Southeastern Brazil. Neotrop. Ichthyol. 10(2):369-382, http:// dx.doi.org/10.1590/S1679-62252012005000013
INTERNATIONAL UNION FOR CONSERVATION OF NATURE IUCN. 2013. IUCN Red List of Threatened Species. http:// www.iucnredlist.org/ (Accessed on 10 December 2013).

LOPES, R.G., RODRIGUES, E.S., PUZZI, A., PITA, J.B., COELHO, J.A.P. \& FREITAS, M.L. 1993. Levantamento ictiofaunistico em um ponto fixo na baia de santos, Estado de São Paulo. Brasil. Bol. Inst. Pesca. 20:7-20.

MACHADO, A.B.M., MARTINS, C.S., DRUMMOND, G.M. 2005. Lista da fauna brasileira ameaçada de extinção: incluindo as espécies quase ameaçadas e deficientes em dados. Belo Horizonte: Fundação Biodiversitas.

MATSUURA, Y. 1995. Os ecossistemas brasileiros e os principais macrovetores de desenvolvimento. Subsídio ao Planejamento da Gestão Ambiental. Projeto Cenários para o Planejamento da Gestão Ambiental (MMA/PNMA), Brasília, DF, p. 39-104.

MUTO, E.Y., SOARES, E.S.H. \& ROSSI-WONGTSCHOWSKI, C.L.D.B. 2000. Demersal fish assemblages Off São Sebastião, southeastern Brazil: Structure and environmental conditioning factors (summer 1994). Rev. Bras. Ocean. 48(1):9-27.

NAMORA, R.C., MOTTA, F.S. \& GADIG, O.B.F. 2009. Caracterização da pesca artesanal da Praia dos Pescadores, Município de Itanhaém, costa centro-sul do Estado de São Paulo. Arq. Ciên. Mar. 42(2):60-67.

SALAS, S., CHUENPAGDEE, R., CHARLES, A. \& SEIJO, J.C. 2011. Coastal fisheries of Latin America and the Caribbean. FAO Fisheries and Aquaculture Technical Paper. No. 544. Rome, FAO. p. 430

SECRETARIA DO MEIO AMBIENTE DO ESTADO DE SÃO PAULO - SEMA/ SP. 2014. Decreto ${ }^{\circ} 60.133$, de 7 de fevereiro de 2014. Declara as espécies da fauna silvestre ameaçadas de extinção, as quase ameaçadas e as deficientes de dados para avaliação no Estado de São Paulo e dá providências correlatas. Diário Oficial do Estado de São Paulo, São Paulo, Poder Executivo, 8 fev. 2014. Seção 1.

VASCONCELLOS, M., GASALLA, M.A. 2001. Fisheries catches and the carrying capacity of marine ecosystems in southern Brazil. Fish. Res. 50:279-295, http://dx.doi.org/10.1016/S0165-7836(00)00217-4

VASCONCELLOS, M., DIEGUES, A.C.S.A. \& SALES, R.R. 2007. Limites e possibilidades na gestão da pesca artesanal costeira. In: Costa, A.L. (Org.) Nas Redes da Pesca Artesanal. Brasília: IBAMA MMA, p. 15-83.

VASCONCELOS, M., DIEGUES, A.C. \& KALIKOSKI, D.C. 2011. Coastal fisheries of Brazil. In: Salas, S., Chuenpagdee, R., Charles, A., Seijo, J.C. (eds.) Coastal fisheries of Latin America and the Caribbean. FAO Fisheries and Aquaculture Technical Paper. No. 544. Rome, FAO, p. 73-116.

ZANI-TEIXEIRA, M.L. \& PAIVA-FILHO, A.M. 1981. Contribuição ao conhecimento da fauna íctica costeira de região de Peruíbe, SP. II: Diversidade faunística. Rev. Bras. Biol. 41(2):291-294. 